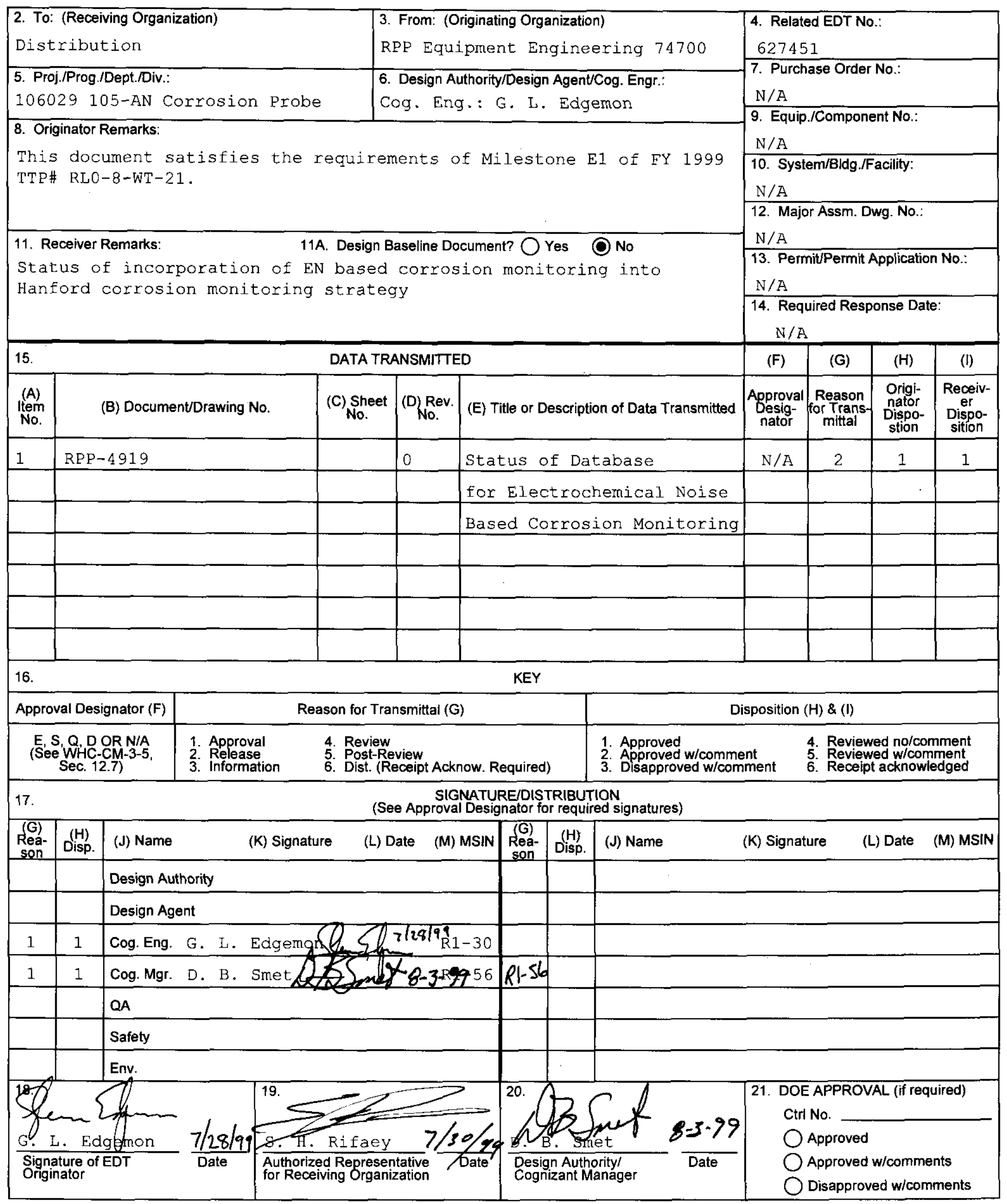




\title{
Status of Database for Electrochemical Noise Based Corrosion Monitoring
}

\section{G. L. Edgemon}

Lockheed Martin Hanford Corporation

Richland, WA 99352

U.S. Department of Energy Contract DE-AC06-96RL13200

\author{
EDT/ECN: 627451 \\ Org Code: 74700 \\ UC: 2030 \\ B\&R Code: EW4 010000 \\ Charge Code: 106029 \\ Total Pages: 10
}

Key Words: corrosion probe, multi-function probe, electrochemical noise, data analysis

Abstract: Corrosion probe database status. This document meets the requirements of Milestone E1 of FY 1999 TTP\# RL0-8-WT-21.

TRADEMARK DISCLAIMER. Reference herein to any specific commercial product, process, or service by trade name, trademark, manufacturer, or otherwise, does not necessarily constitute or imply its endorsement, recommendation, or favoring by the United States Government or any agency thereof or its contractors or subcontractors.

Printed in the United States of America. To obtain copies of this document, contact: Document Control Services, P.O. Box 950, Mailstop H6-08, Richland WA 99352, Phone (509) 372-2420; Fax (509) 376-4989.
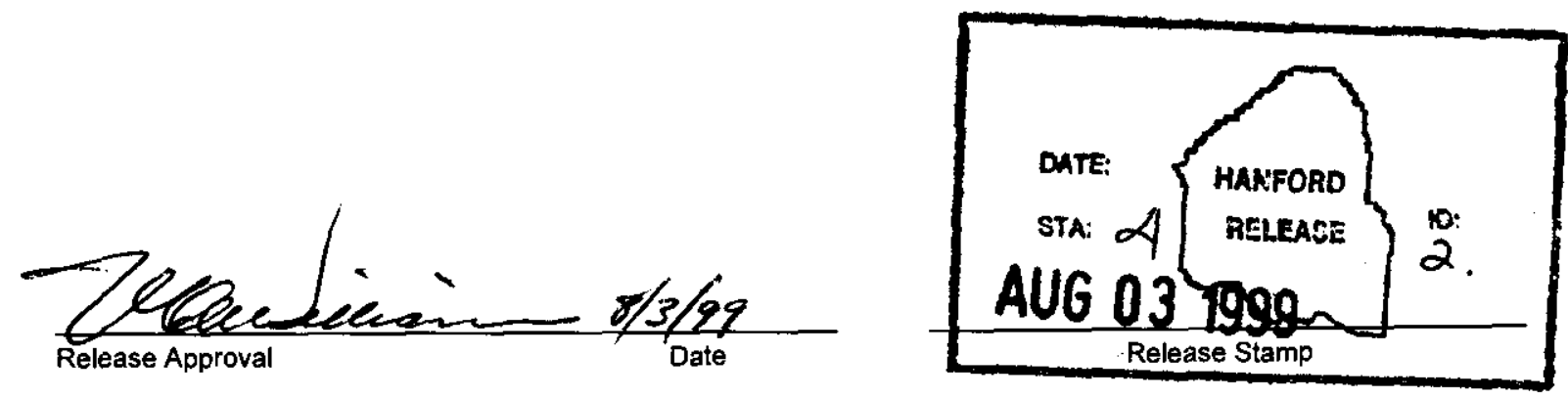

Approved For Public Release 
Underground storage tanks made of mild steel are used to contain radioactive waste generated by plutonium production at the Hanford Site. Corrosion of the walls of these tanks is a major issue. Corrosion-related failure of waste tank walls could lead to the leakage of radioactive contaminants to the soil and groundwater. It is essential to monitor corrosion conditions of the tank walls to determine tank integrity and ensure safe waste storage until retrieval and final waste disposal can be accomplished.

Corrosion monitoring/control is currently provided at the Hanford Site through a waste chemistry sampling and analysis program. In this process, tank waste is sampled, analyzed and compared to a selection of laboratory exposures of coupons in simulated waste. Tank wall corrosion is inferred by matching measured tank chemistries to the results of the laboratory simulant testing. This method is expensive, time consuming, and does not yield real-time data. A project to improve the Hanford Site's corrosion monitoring strategy was started in 1995.

A small number of techniques have previously been tried at Hanford and elsewhere within the DOE complex to determine the corrosivity of nuclear waste stored in underground tanks [1]. Coupon exposure programs, linear polarization resistance (LPR), and electrical resistance techniques have all been tried with limited degrees of success. These techniques are most effective for monitoring uniform corrosion, but are not well suited for early detection of localized forms of corrosion such as pitting and stress corrosion cracking (SCC). Pitting and SCC have been identified as the most likely modes of corrosion failure for Hanford Double Shell Tanks (DST's) [2-3].

Over the last 20 years, a new corrosion monitoring system has shown promise in detecting localized corrosion and measuring uniform corrosion rates in process industries [4-20]. The system measures electrochemical noise (EN) generated by corrosion. The term EN is the term used to describe low frequency fluctuations in current and voltage associated with corrosion. In their most basic form, EN-based corrosion monitoring systems monitor and record fluctuations in current and voltage over time from electrodes immersed in an environment of interest. Laboratory studies and field applications have shown that different types of corrosion create different patterns of current and voltage fluctuations (i.e.: EN). By monitoring the EN produced by corrosion on electrodes immersed in Hanford waste tanks, waste tank corrosion conditions can be observed in real-time.

A two-year laboratory study was started at Hanford in 1995 to provide a technical basis for using EN-based systems to monitor corrosion in Hanford's nuclear waste tanks [21]. Based on this study, a prototype system was constructed and deployed in DST 241-AZ-101 in August, 1996 [22]. Based on the successful demonstration of this prototype, a full-scale system was designed and installed into DST 241-AN-107 in September 1997 [23]. A second-generation full-scale system similar to the 241-AN-107 system was designed, fabricated and installed in 241-AN-102 in August 1998 [24]. A third-generation full-scale system with numerous design improvements is scheduled for deployment into 241-AN-105 in fiscal year 1999 [25]. 
An effort is underway to augment the existing corrosion control program at Hanford (waste chemistry sampling/analysis) by incorporating real-time corrosion data collected from the newly developed EN based corrosion monitoring systems. This document describes the potential merger of these two corrosion monitoring strategies.

\section{Existing Hanford Waste Composition Specifications}

Initial corrosion control specifications for DSTs at Hanford were developed from the results of an extensive SCC testing program at the Savannah River Site (SRS) [26]. It was found that corrosion of low carbon steels was dependent on hydroxide, nitrite, and nitrate concentrations. Addition of minor constituents such as carbonate, phosphate, sulfate, silicate, fluoride, and chloride in low concentrations did not have a significant impact on corrosion behavior of test materials. Thus, SRS corrosion specifications focussed on the waste concentrations of hydroxide, nitrate, and nitrite. Because the tank materials used at SRS are similar to the DST steels at Hanford, corrosion specifications developed from the SRS tests were applied to tank farm operations at Hanford. Since the SRS testing program focussed on SCC, which generally occurs at temperatures above normal Hanford tank temperatures, and on waste types that did not adequately describe all of the Hanford waste tanks, the new corrosion specifications were considered as an interim measure of corrosion control until further testing could be performed to augment the SRS results.

In 1980, the Hanford Waste Tank Corrosion Studies were initiated to provide the necessary corrosion data to define safe operating conditions for the Hanford DSTs [26]. Rockwell Hanford personnel supplied tank chemistry information to Pacific Northwest Laboratories who performed tests on several thousand coupons in various environments and statistically interpreted the data. Corrosion was again found to be largely controlled by waste concentrations of hydroxide, nitrate, and nitrite. Current Hanford corrosion specifications are based on these studies [27].

Regular time intervals for tank waste chemistry sampling for corrosion control are not defined in the current site Authorization Basis $(\mathrm{AB})$ or the site Operational Specification Documents (OSDs). Site OSD T-151-00007 specifies only that tank contents must comply with the given waste composition limits. Tank inputs must be controlled so that tank contents comply with composition limits following a transfer. Verification of compliance with composition limits is not necessary for transfers from catch tanks containing waste previously verified to comply with DST composition limits, or condensate from DSTs. For all other transfers, it must be verified that the composition limits in the receiving tank will not be exceeded prior to transferring additional waste into a tank.

Time allowed for recovery from out of specification waste chemistry discoveries is not defined in the current site $\mathrm{AB}$ or OSDs. If a tank content composition limit is violated, waste transfers in progress are stopped and the Tank Farm Operations Shift Manager is notified. The Shift Manager then notifies the managers of Tank Farm Operations and Tank Farm Engineering. Additional notifications are made per WHC-IP-0842, Volume II, Section 5.10 and a recovery plan is developed. Recovery plans include actions to be taken to return tank chemistry to the proper operating specifications. No time limit is specified in the current $\mathrm{AB}$ or OSDs for 
performance and completion of the recovery plan. Tanks 241-AP-104, 241-AY-101, 241-AN102 and 241-AN-107 continue to be operated even though they have remained out of corrosion control waste chemistry specification limits for long periods of time (up to several years).

\section{EN Based Corrosion Monitoring}

Due to difficulties in consistently maintaining the Hanford Site waste chemistry corrosion control specification in all the Hanford DSTs and recent revelations concerning the corrosivity of potential waste chemistries that could be encountered during the DST sludge washing process, the use of EN based corrosion monitoring systems has been proposed as a way to improve the safety and efficiency of the existing Hanford Site corrosion control program [28]. For many years, EN has been observed during corrosion and other electrochemical reactions, and the phenomenon is well established. Typically, EN consists of low frequency $(<1 \mathrm{~Hz})$ and small amplitude signals that are spontaneously generated by electrochemical reactions occurring at corroding or other surfaces. Laboratory studies and recent reports on field applications have reported that EN analysis is well suited for monitoring and identifying the onset of localized corrosion, and for measuring uniform corrosion rates [4-20].

Like most EN based corrosion-monitoring systems, the Hanford tank corrosion monitoring systems are designed to measure instantaneous fluctuations in corrosion current and potential between sets of three nominally identical mild steel electrodes (a working, a counter, and a pseudo-reference electrode) immersed in the waste. The fluctuations in current and potential are caused by corrosion of the electrodes. It has been shown that each type of corrosion phenomenon presents a unique relationship between corrosion current and potential transients in the temporal data [4-23].

In addition to eight channels of corrosion monitoring, the Hanford systems also incorporate other instrumentation such as thermocouples, high level detectors, ports for pressure/gas sampling, and strain gauges to monitor the effects of tank operations on the downhole instrumentation [22-25]. In tank portions of the probes have been subjected to site seismic and structural analyses for general service equipment $[29,30]$. These features add functionality to the probe, provide for a better understanding of the relationship between corrosion and other tank operating parameters, and optimize the use of the riser that houses the probe in the tank.

\section{EN System Operation}

Following installation of the in-tank and ex-tank portions of the system, data can be collected from the eight channels of corrosion monitoring electrodes. User configurable software is typically set up to simultaneously collect current and voltage measurements (i.e.: EN) from all eight channels at a rate of one measurement per second. Data is recorded continuously unless interrupted by system fault or manually stopped by the operator. Periodically, data are downloaded for analysis by a member of the Equipment Engineering organization within Lockheed Martin Hanford Corporation (LMHC). Data are subjected to a number of statistical analysis and compared with historical data from other systems, laboratory test data on waste simulants, and EN data from other process chemical industries [21]. Following this process, 
conclusions are drawn about corrosion occurring in the waste tank, system operation, and potential system troubles.

Interpretation of EN based corrosion monitoring data is currently the responsibility of the Equipment Engineering Organization within LMHC. Since corrosion probes are not covered in the current $\mathrm{AB}$ or $\mathrm{OSDs}$, corrosion probe data are not officially used to influence tank farm operations. Equipment Engineering has historically made corrosion control suggestions to Tank Farm Operations based on output from the existing corrosion probes. Changes in the $\mathrm{AB}$ or OSDs are necessary to facilitate a controlled use of corrosion monitoring data in tank farm operation decisions.

Merger of Corrosion Monitoring and Chemistry Sampling Programs

Because the application of EN based corrosion monitoring to Hanford DSTs is still in the development process, a proposed path to facilitate it's incorporation into an OSD or other procedure is to combine it with the existing corrosion chemistry control specification. In tanks containing functional corrosion monitoring systems, the results of any corrosion chemistry sampling and analysis could be compared with corrosion monitoring data collected at the same time. If the results of this comparison are consistently favorable, specific tank operating specifications could be changed to incorporate the use of EN based corrosion monitoring systems instead of the existing waste chemistry control specification.

Data from Existing EN Based Systems

A prerequisite for using EN based corrosion monitoring systems on a large scale at Hanford is to build a sufficiently large tank corrosion database to facilitate interpretation of new data as the number of monitored tanks is increased. The present database of high-quality data from Hanford tanks is insufficient for this purpose at the present time.

Three systems have been installed at Hanford to date with a fourth scheduled for installation in late FY 1999. Despite the collection of over 580 million points of tank corrosion data from these systems, a high quality database of sufficient size is still lacking due to performance problems with the systems. All systems installed to date during the development effort have been hampered by system configuration and hardware issues in collecting high quality data. These problems are correctable, but will demand a dedicated engineering effort.

The 241-AZ-101 system was the first EN system at Hanford and demonstrated that these systems could withstand a waste tank environment. The 241-AZ-101 system was installed in August 1996. Although a great deal of data were collected from a single channel immersed in the waste, the instrument sensitivity was deemed to be too low and monitoring was discontinued in 1999. Although current noise data collected from this tank were of high quality, the corresponding voltage data was not acceptable [22, 31, 32].

Tank 241-AN-107 was instrumented with a larger, more robust system in September 1997 [23]. Electronics were upgraded to correct the voltage sensitivity problem seen in the 241-AZ-101 system. No funding was provided the following year for the necessary level of data analysis to 
validate system performance. In September 1998, data from the 241-AN-107 system were finally analyzed. It was found that data quality was low due to external electrostatic noise pickup along the long data cable that leads from the in-tank probe to the data collection hardware housed outside the tank farm [33]. No funding has been provided since this analysis to troubleshoot or repair the 241-AN-107 system.

In late FY 1998, a system was installed into 241-AN-102 [24]. Instrumentation used on the 241AN-102 system was expected to correct or avoid the data cable noise pickup that plagued the 241-AN-107 system. However, recent analysis of the 241-AN-102 data has revealed problems similar to those experienced with the 241-AN-107 system. Although the new system software greatly speeded the data analysis process, external noise and interference in the data has rendered the existing 241-AN-102 data too questionable for use [34].

A new system is being fabricated for deployment into 241-AN-105 in late FY 1999 [25]. The new system locates the data collection hardware adjacent to the riser housing the in-tank corrosion probe and limits the data cable length to less than 10 feet. It is expected that this change in configuration and numerous protective measure taken in the area of cable shielding will correct data cable noise pickup problems. Other components on the 241 -AN-105 system are similar to the 241-AN-102 system. If the 241-AN-105 system functions properly, it is expected that the 241-AN-102 and 241-AN-107 systems will be upgraded to match the configuration of the 241-AN-105 system. Once all three systems come on-line, the waste tank EN database will grow rapidly.

\section{Summary and Conclusions}

Hanford DSTs have historically been operated for long periods of time despite being outside the bounds of proper corrosion control chemistry specification. Currently, DSTs 241-AP-104, 241AY-101, 241-AN-102 and 241-AN-107 are being operated, and have been operated for a number of years, despite being out of corrosion control specification. As the Hanford DSTs continue to age, corrosion control at Hanford will become more and more important. Corrosion-related failure of waste tank walls could lead to the leakage of radioactive contaminants to the soil and groundwater. It is essential to monitor corrosion conditions of the tank walls to determine tank integrity and ensure safe waste storage until retrieval and final waste disposal can be accomplished.

Corrosion monitoring/control is currently provided at the Hanford Site through a waste chemistry sampling and analysis program. In this process, tank waste is sampled, analyzed and compared to a selection of laboratory exposures of coupons in simulated waste. Tank wall corrosion is inferred by matching measured tank chemistries to the results of the laboratory simulant testing. This method is expensive, irregularly scheduled, time consuming, potentially inaccurate, and does not yield real-time data. The existence of four out of specification tanks is a testament to the shortcomings of the current corrosion control program at Hanford.

Over the last 20 years, a new corrosion monitoring technique has shown promise in detecting localized corrosion (pitting and SCC) and measuring uniform corrosion rates in process industries outside of Hanford. Pitting and SCC have been identified as the most likely modes of 
corrosion failure for Hanford DSTs. This new system measures electrochemical noise (EN) created by corrosion. In an effort to improve the Hanford Site's corrosion monitoring program, a project to develop and integrate EN based corrosion monitoring into the existing corrosion control program was started in 1995.

Three systems have been installed at Hanford to date with a fourth scheduled for installation in late FY 1999 and a fifth in FY 2000. Currently, two active systems are operating, one in 241$\mathrm{AN}-107$ and one in 241-AN-102. Interpretation of EN based corrosion monitoring data is currently the responsibility of the Equipment Engineering Organization within LMHC. Since corrosion probes are not covered in the current $\mathrm{AB}$ or OSDs, corrosion probe data are not yet officially used to influence tank farm operations. Changes in the AB or OSDs are necessary to facilitate a controlled use of corrosion monitoring data in tank farm operation decisions.

Because the application of EN based corrosion monitoring to Hanford Tanks is still in the development process, one possibility for facilitating it's incorporation into an OSD or other procedure is to combine it with the existing corrosion chemistry control specification. In tanks containing functional corrosion monitoring systems, the results of any corrosion chemistry sampling and analysis could be compared with corrosion monitoring data collected at the same time. If the results of this comparison are consistently favorable, specific tank operating specifications could be changed to incorporate the use of EN based corrosion monitoring systems instead of the existing waste chemistry control specification. This process could be continued until all DSTs are instrumented.

A prerequisite for using EN based corrosion monitoring systems as the primary means of corrosion monitoring at Hanford is to build a sufficiently large tank corrosion database to facilitate interpretation of new data as the number of monitored tanks is increased. The present database of high-quality data from Hanford tanks is insufficient for this purpose at the present time. Systems installed to date during the development effort have been hampered by system configuration and hardware issues in collecting high quality data. A new system is being fabricated for deployment into 241-AN-105 in late FY 1999. The new system is expected to correct problems experienced with previous systems installed in 241-AN-107 and 241-AN-102. If the 241-AN-105 system functions properly, it is expected that the 241-AN-102 and 241-AN107 systems will be upgraded to match the configuration of the $241-\mathrm{AN}-105$ system. Once all three systems properly come on-line, the database of high quality EN data is expected to grow rapidly and the systems will be ready for official use in the tank farms.

\section{References}

[1] R.K. Shukla, A.J. Perkins, P.M. Bourgeois, R.J. Jaramins, W.G. Secen, and, D.J. Stroud, Corrosion Monitoring of High Level Waste Storage Tank 8-D2 at the West Valley Demonstration Project, CORROSION/94, paper no. 121, (Houston, TX: NACE International, 1994).

[2] D.C. Lini, Compilation of Hanford Corrosion Studies, Atlantic Richfield Hanford Company Report, ARH-ST-111, UC-70, July, 1975. 
[3] G. L. Edgemon and R. P. Anantatmula, Hanford Waste Tank System Degradation Mechanisms Report, Westinghouse Hanford Company Report, WHC-SD-WM-ER-414, Rev. 1, October, 1996.

[4] T. Haygard and J. R. Williams, Trans. Farad. Soc. 57, (1961): p. 2288.

[5] P. Bindra, et al., Discussions of Faraday Soc. 56, (1974): p. 189.

[6] M. Fleischmann, et al., Surface Science 100-101, (1980): p. 583.

[7] G.J. Bignold and M. Fleischmann, Electrochemical Acta 19, (1974): p. 363.

[8] E. Budevski, et al., Electrochemical Acta 28, (1983): p. 925.

[9] G. Blanc, et al., Electrochemical Acta 23, (1978): p. 337.

[10] K. Hladky and J. L. Dawson, Corrosion Science 22, (1982): p. 231.

[11] U. Bertocci, Electrochemical Noise Analysis and Its Application to Corrosion, CORROSION/89, paper no. 24, (Houston, TX: NACE International, 1989).

[12] J.L. Dawson, D.M. Farrell, P.J. Aylott, and K. Hladky, Corrosion Monitoring Using Electrochemical Noise Measurements, CORROSION/89, paper no. 31, (Houston, TX: NACE International, 1989).

[13] D.A. Eden, A. N. Rothwell, and J.L. Dawson, "Electrochemical Noise for Detection of Susceptibility to Stress Corrosion Cracking, CORROSION/91, paper no. 444, (Houston, TX: NACE International, 1991).

[14] D.M. Farrell, Industrial Corrosion 9, (1991): p. 7.

[15] A.N. Rothwell, T.G. Walsh, and W.M. Cox, On Line Corrosion Investigation and Surveillance - Chemical Plant Case Studies, CORROSION/91, paper no. 170, (Houston, TX: NACE International, 1991).

[16] J.L. Dawson, et al., On-line Monitoring of Continuous Process Plants, ed. D. Butcher, (Ellis Horwood, NY, 1983).

[17] D.M. Farrell, W.M. Cox, and D. Gearey, Multi-System Corrosion Monitoring in a Cyclic Reheat Test Facility; Phase 1, Electric Power Research Institute Report, CS-5776, 1988.

[18] D.M. Farrell, W.M. Cox and D. Gearey, Multi-System Corrosion Monitoring in FGD Systems; Phase 2, Electric Power Research Institute Report, CS-5734, 1988. 
[19] B.C. Syrett and W.M. Cox, in: Proc. First Int. Symposium on Electrochemical Noise Measurements for Corrosion Applications, ASTM STP 1277, eds. J.R. Kearns, J.R. Scully, P.R. Roberge, D.L. Reichert, and J.L. Dawson, (American Society for Testing and Materials, Philadelphia, PA, 1996) p. 173.

[20] C.A. Lotto and R.A. Cottis, Corrosion 45, (1989): p. 136.

[21] G.L. Edgemon and G.E.C. Bell, Technical Basis for Electrochemical Noise Based Corrosion Monitoring of Underground Nuclear Waste Storage Tanks, Westinghouse Hanford Company Report, WHC-SD-WM-TI-772, November, 1996.

[22] G.L. Edgemon, J.L. Nelson, P.C. Ohl, and G.E.C. Bell, Hanford Prototype Corrosion Probe Operational Experience, CORROSION/97, paper no. 97124, (Houston, TX: NACE International, 1997).

[23] G.L. Edgemon, J.L. Nelson, and G.E.C. Bell, Design of an Electrochemical Noise Based Corrosion Monitoring Probe for High Level Nuclear Waste Storage Tanks, CORROSION/98, paper no. 98175, (Houston, TX: NACE International, 1998).

[24] G.L. Edgemon and J. L. Nelson, Design of Second-Generation Corrosion Monitoring Probe, Lockheed Martin Hanford Company Report, HNF-2517, Rev. 0, April, 1998.

[25] G.L. Edgemon and J. L. Nelson, Design of Multi-Function Hanford Tank Corrosion Monitoring System, Lockheed Martin Hanford Company Report, HNF-4285, Rev. 0, April, 1999.

[26] N. W. Kirch, Technical Basis for Waste Tank Corrosion Specifications, Rockwell Hanford Company Report, SD-WM-TI-150, Rev. 0, August, 1984.

[27] L. Ross, Unclassified Operating Specifications for the 241-AN, $A P, A W, A Y, A Z$, \& $S Y$ Tank Farms, Tank Farms Operating Specification Document, OSD-T-151-00007, Rev. H-21, September, 1998.

[28] M. J. Danielson, L. R. Bunnel, Sludge Washing Materials Study: The Behavior of Carbon Steel in a Dilute Waste Environment, Westinghouse Hanford Company Report, TWRSPP-94-025, Rev. 0, August, 1995.

[29] H. P. Shrivastava, Structural Evaluation of Second Generation Double Shell Tank Corrosion Probe Tree, Lockheed Martin Hanford Company Report, HNF-SD-WM-CN090, Rev. 0, June, 1997.

[30] H. S. Ziada, Analysis of the Effects of Corrosion Probe on Riser 241-AN-102-WST-16 During Seismic Event, Numatec Hanford Company Report, HNF-3162, Rev. 0, November, 1998. 
[31] G. L. Edgemon, J. L. Nelson, P. C. Ohl, Prototype Corrosion Probe Four Month Status Report, Lockheed Martin Hanford Company Report, WHC-SD-WM-TI-796, Rev. 0, December, 1996.

[32] G.L. Edgemon, Tank 241-AZ-101 Prototype Corrosion Probe Two-Year Status Report, Lockheed Martin Hanford Company Report, HNF-3416, Rev. 0, September, 1998.

[33] G.L. Edgemon, Corrosion Data From Hanford High-Level Waste Tank 241-AN-107, Lockheed Martin Hanford Company Report, HNF-3414, Rev. 0, September, 1998.

[34] G.L. Edgemon, Data Analysis and Reduction in Hanford's Corrosion Monitoring Systems, Lockheed Martin Hanford Company Report, HNF-4653, Rev. 0, July, 1999. 